\title{
20 ANOS DE GRUPODE ESTUDOS MULTIPROFISSIONAL EM SAÚDE DO ADULTO - GEMSA
}

Maria de Fátima Mantovani ${ }^{1}$

A pesquisa tem na academia seu lugar de moradia, ela constitui um dos pilares da missão das Universidades, junto com o ensino e a extensão, e se aninha em laboratórios, núcleos e grupos de pesquisa. Assim constituída, a pesquisa alavanca o progresso nas mais variadas áreas do conhecimento; as Universidades brasileiras tem sido palco para as descobertas e, assim, desempenham o seu papel social. Aos professores pesquisadores cabe o papel de aprofundar o conhecimento e sempre respeitando as perspectivas teórico metodológicas inerentes a elas.

No Curso e Departamento de Enfermagem da Universidade Federal do Paraná, desde sua criação, havia movimentos solitários de professores pesquisadores. Mas, após o incentivo da Rede de Pós-Graduação em Enfermagem da Região Sul - REPENSUL, no início da década de 90 do século passado, iniciou-se a criação de grupos de pesquisa. O primeiro deles foi o GEMSA, criado em dezembro de 1993, e cuja primeira pesquisa, financiada pelo CNPq, versava sobre as condições de saúde dos adultos de Curitiba, sob a condução de sua

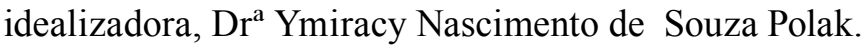

O GEMSA nasceu multiprofissional, agregava enfermeiros de campo e docentes, estatísticos e pedagogos; com base em seus princípios definiu-se quem é este adulto e busca-se, desde então, conhecer suas necessidades e estabelecer estratégias para o alcance da saúde e qualidade de vida. Durante esses 20 anos, muitos fizeram parte do Grupo, aprendendo a desenvolver pesquisa, a construir e compartilhar conhecimento; seus membros se fortaleceram e se aperfeiçoaram, o que os capacitou para a criação de outros grupos de pesquisa. Atualmente, o Grupo conta com 8 pesquisadores doutores e 38 estudantes da Universidade Federal do Paraná, sendo 14 orientandos de iniciação científica, 14 mestrandos - 9 do Mestrado Acadêmico e 5 do Mestrado profissional, e 9 doutorandos, além de enfermeiros e acadêmicos de enfermagem de outras Universidades do Estado. As linhas de pesquisa proporcionaram aprofundamentos em diversos objetos de estudo, com destaque para doenças crônicas, violência e educação em saúde.

A história da revista Cogitare Enfermagem e do GEMSA tem a mesma fonte de criação e ambos continuam firmes no propósito de divulgar e buscar conhecimento, para fortalecer a prática profissional e dar a esta subsídios para sua excelência. Ao Grupo cabe pesquisar, buscar fomento e responder às necessidade pautadas nas pesquisas, e à Revista oportunizar a divulgação dos resultados dessas. Este jovem Grupo de 20 anos, com muitos caminhos a descortinar, se compromete a dar continuidade ao seu trabalho e fortalecer, ainda mais, a pesquisa na área de saúde do adulto.

${ }^{1}$ Enfermeira. Doutora em Enfermagem. Professora da Graduação e dos Programas de Pós-Graduação da Universidade Federal do Paraná. Coordenadora de Iniciação Científica e Integração Acadêmica da UFPR. Bolsista Produtividade 2 CNPq. Membro do GEMSA. 


\title{
20 YEARS OF THE MULTI-PROFESSIONAL STUDIES GROUP IN ADULT HEALTH - GEMSA
}

\author{
Maria de Fátima Mantovani ${ }^{1}$
}

In academia, research has its place of residence; it constitutes one of the pillars of the universities' mission, along with teaching and extension courses, and is found in the laboratories and research centers and groups. Thus constituted, research levers progress in the most varied areas of knowledge, Brazilian universities have been the stage for discoveries, and in this way have performed their social role. To the professors, through their research, has fallen the role of deepening knowledge, always respecting the methodological theoretical perspectives which are inherent to them. $(?=$ 'the inherent methodological theoretical perspectives? OU: 'respecting the methodological theoretical perspectives and all that is inherent to them?)

Ever since the Federal University of Paraná's Nursing Course - and Department - was set up, there had been unconnected movements of professors conducting research. Following the incentive of REPENSUL, the Post-Graduate Network in Nursing (Southern Region), at the start of the last decade of the last century, the creation of research groups was started. The first of these was GEMSA, set up in December 1993, and whose first research, financed by the National Council for Scientific and Technological Development (CNPq), covered the health of adults in Curitiba, under the leadership of its creator, Dr Ymiracy Nascimento de Souza Polak.

GEMSA began as a multidisciplinary group, bringing together field nurses and lecturers, statisticians and teachers; based in its principles, who the adult is was defined; and since then, it has been sought to investigate their needs and to establish strategies for achieving health and quality of life. During these twenty years, many have taken part in the Group, learning how to undertake research and to build and share knowledge; its members strengthened and improved their skills, which enabled them to create other research groups in their turn. The Group currently has 8 doctorate researchers and 38 students of the Federal University of Paraná, these being 14 orientandos de iniciação científica, 14 Master's Degree students - 9 from the academic Master's course and 5 from the professional Master's course, and $9 \mathrm{PhD}$ students, in addition to nurses and students of nursing from other universities in the state. The lines of research allow the exploration in depth of various study objects, with an emphasis on chronic illnesses, violence, and health education.

The history both of the journal Cogitare Enfermagem and of GEMSA have the same source of creation, and both continue firm in the purpose of seeking and disseminating knowledge, so as to strengthen their professional practice and to provide them with support for their excellence. To the Group it falls to research, to seek support, and to respond to the needs, grounded in the research; and to the Journal, it falls to disseminate the results. This young Group, of twenty years, with many paths still to be opened, is dedicated to continue with its work and to strengthen, even further, research in the area of adult health.

${ }^{1}$ Nurse. PhD in Nursing. Professor on the Under-graduate Course and on the Post-Graduate Programs of the Federal University of Paraná. Coordenadora de Iniciação Científica e Integração Acadêmica da UFPR. Productivity Fellow II CNPq. Member of GEMSA.

Cogitare Enferm. 2013 Abr/Jun; 18(2):211-3 


\section{AÑOSDE GRUPO DE ESTUDIOS MULTIPROFESIONAL ENSALUDDEL ADULTO - GEMSA}

Maria de Fátima Mantovani ${ }^{1}$

La vivienda de la investigación está ubicada en academia, siendo ella, la investigación - que se organiza en laboratorios, núcleos y grupos de investigación - una de las pilastras de la misión de las Universidades, así como la enseñanza y la extensión. De esa forma, por medio de la investigación que impulsa el progreso en las más variadas áreas del conocimiento, las Universidades brasileñas vienen siendo palco para descubiertas y, así, desempeñan su papel social. A los profesores investigadores se destina el papel de profundizar el conocimiento, siempre respetando las perspectivas teórico metodológicas, inherentes a ellas.

Hubo movimientos solitarios de profesores investigadores en el Curso y Departamento de Enfermería de Universidad Federal de Paraná desde su creación. Pero, después del incentivo de la Red de Posgrado en Enfermería de la Región Sur - REPENSUL, en el comienzo de la década de 90 del siglo pasado, empezó la creación de grupos de investigación. El primero de ellos fue GEMSA, originado en diciembre de 1993, y cuya primera investigación, financiada por CNPq, trataba de las condiciones de salud de los adultos de Curitiba, bajo la conducción de su idealizadora, Dr ${ }^{\mathrm{a}}$ Ymiracy Nascimento de Souza Polak.

GEMSA nació multiprofesional, agregaba enfermeros de campo y docentes, estadísticos y pedagogos; con base en sus principios, se definió quien es este adulto y, desde entonces, se busca conocer sus necesidades y establecer estrategias para alcanzar su salud y su cualidad de vida. Durante eses 20 años, muchas personas hicieron parte del Grupo, aprendiendo a desarrollar investigación, a construir y compartir conocimiento; sus miembros se fortalecieron y se perfeccionaron, lo que los capacitó para la creación de otros grupos de investigación. Hoy, el Grupo tiene 8 investigadores doctores y 38 estudiantes de Universidad Federal de Paraná, siendo 14 de iniciación científica, 14 maestrandos - 9 del Maestrado Académico y 5 del Maestrado profesional, y 9 doctorandos, además de enfermeros y académicos de enfermería de otras Universidades del Estado. Los campos de investigación resultan en perfeccionamiento en diversos objetos de estudio, con destaque para enfermedades crónicas, violencia y educación en salud.

Las historias de la revista Cogitare Enfermagem y de GEMSA tienen la misma fuente de creación y los dos siguen firmes en el propósito de divulgar y buscar conocimiento, a fin de fortalecer la práctica profesional y dar a esta subsidios para su excelencia. Es responsabilidad del Grupo, por lo tanto, investigar, buscar fomento y responder a las necesidades pautadas en las investigaciones, y de la Revista dar oportunidad de divulgación de los resultados de estas. Este joven Grupo de 20 años, con muchos caminos a descortinar, se compromete a dar continuidad a su trabajo y corroborar, todavía más, la investigación en el área de salud del adulto.

'Enfermera. Doctora en Enfermería. Profesora de la Graduación y de los Programas de Posgrado de la Universidad Federal de Paraná. Coordinadora de Iniciación Científica e Integración Académica de UFPR. Becaria Productividad 2 CNPq. Miembro de GEMSA. 